THURSDAY, FEBRUARY 3, $1870^{\circ}$

\section{THE ATMOSPHERIC-GERM THEORY}

WE have heard much during the last week or two concerning the presence of organic matter in the atmosphere, and the degree to which this is filled with "germs" of living things. It would have been better, perhaps, had it been always pointed out more distinctly that the two expressions were by no means uniformly convertible. There is unquestionably much mere organic débris in the atmosphere which nobody could regard as germs of living things.

The transition, in the minds of many at the present day, however, from the idea of organic matter in the atmosphere, to the identification of this: with germs of actual animal and vegetable organisms, occurs only too easily. The air is supposed by them to be teeming with potential living things most varied in kind. Each square foot of atmosphere is thought to contain representatives of innumerable varieties, which are only awaiting the advent of suitable conditions in order to commence their growth and development. Men talk most glibly about germ-theories of disease, and the share which germs take in the origin of epidemics, as though these were proven facts of science rather than, as they are at present, mere questionable hypotheses. And, just as these germ-theories concerning epidemic disease have grown out of the more general panspermic doctrine, so did this doctrine itself grow out of the great "spontaneous generation" controversy somewhat more than a century ago. As it was with the derived, so was it with the original doctrine: in each case it was produced, not so much on account of any direct evidence in favour of the existence of such germs, but rather on account of the inherent difficulty in the explanation of the subject to which it referred. Previous to the period mentioned, however, no such doctrine had been started. There were, of course, the old pantheistic doctrines of Anaxagoras and his followers-the notion of the universal diffusion of an active principle or pov̂s pervading all things, which was itself the cause and source of all the life on our globe: there was also the doctrine of Leibuitz, concerning "Monads," as centres of force and life existing in all things ; but anything like the present "panspermic" doctrine was still wanting.

The Aristotelian notions concerning the "spontaneous generation" of even complex living things, received a severe blow by the experimental demonstration of Rédi, in 1638 , before one of the Italian academies. He showed that the larvæ found in putrefying flesh had been deposited there by flies, and had not been engendered (as had been previously supposed) by changes taking place in the flesh itself. Hence a very desirable modification of their views was necessitated on the part of the heterogenists. It was not, however, till about a century after this that the "spontaneous generation" doctrines were again prominently brought before the scientific world. Then, too, they appeared in a form more suited to our present notions. The long controversy carried on between Needham, the English champion of heterogeny, and the Abbe Spallanzani, resulted in the promulgation by the latter of the celebrated "panspermic" doctrine. The question pressing for solution was, What is the mode of origin of the myriads of the lowest forms of life which so soon teem in organic solutions? According to Needham many of these lowest living things had been evolved de novo owing to changes taking place in the organic matter of the infusion; according to Spallanzani they had been ultimately derived from "germs" which, floating everywhere in the atmosphere, had, in spite of all precautions, gained access to the solutions. Spallanzani did not pretend that he had seen these "germs," their existence was a mere postulation and no other evidence of their reality was alleged than the occurrence of the very phenomena which their presence was supposed to explain. His position was interpretable in this way. He seemed to think that such new evolution of life was impossible. If living things occurred, therefore, they must have originated from pre-existing germs. Against unchangeable convictions of this kind, occurring either then or now, of course no amount of experimental evidence would be of any avail. Spallanzani preferred to believe that the atmosphere carried with it everywhere myriads of germs of elementary organisms, or, at all events, sundry principes préorganisés, invisible and imaginary though they might be. On this subject he says*:-"The infusorial animalcules undoubtedly take origin, in the first place, from certain principes préorganisés; but these principes, are they eggs, germs, or other similar corpuscles ?" To which he most honestly adds :- "If it is necessary to offer facts in reply to this question, I frankly acknowledge that we have no certain knowledge on the subject."

Bonnet was the contemporary of Spallanzani, and he was also the advocate of a doctrine similar in its tendency, though infinitely more extravagant. Bonnet's leading notion of the "embôitement des germes" is thus illustrated in one of the earlier chaprers of his work t:- "The sun, a million times larger than the earth, has for an ultimate constituent a globule of light, of which several thousand millions enter at once into the eye of an animal twenty million times smaller than a flesh worm .... But reason can penetrate even further. From this globule of light it can see issue another universe having its sun, its planets, its plants, its animals, and amongst these last an animalcule which is to this new world what that, of which I have just spoken, is to the world which we inhabit." Now, it would certainly be wrong to restrain any man in the exercise of his fancy, but it surely is deplorable when we find the results of such exercise-such mere figments of the imagination as this-warping the reasonings of succeeding generations when they come gravely to argue about questions of fact.

Such, then, has been the origin of the "panspermic" doctrine. Its first supporters commenced with assumptions, which could only be supported by the occurrence of the very phenomena that were the subjects in dispute, and to explain which the assumptions had been started. This was the doctrine of which M. Pasteur first attempted the experimental verification. How far he succeeded in the attempt is another question. On the part of those who first promulgated the "panspermic" doctrine, there certainly was nothing but mere fancy and hypothesis.

* Opuscles de Physíques, animale et végétale. Pavie, 1787. Torn. I. p. 230 .

† Considerations sur les Corps Organisées. Amsterdam : 1772 . 